\title{
Correction to: The perception of emotional cues by children in artificial background noise
}

\author{
Emilia Parada-Cabaleiro ${ }^{1}\left[\right.$ ] Anton Batliner ${ }^{1} \cdot$ Alice Baird $^{1} \cdot$ Björn Schuller $^{1,2}$
}

Accepted: 1 September 2021 / Published online: 18 November 2021

(c) The Author(s) 2021

\section{Correction to: International Journal of Speech Technology (2020) 23:169-182 https://doi.org/10.1007/s10772-020-09675-1}

The article 'The perception of emotional cues by children in artifcial background noise', written by Emilia ParadaCabaleiro, Anton Batliner, Alice Baird and Björn Schuller, was originally published Online First without Open Access. After publication in volume 23, issue 1, page 169-182 it has been decided to make the article an Open Access publication. Therefore, the copyright of the article has been changed to (c) The Author(s) 2020 and the article is forthwith distributed under the terms of the Creative Commons Attribution 4.0 International License, which permits use, sharing, adaptation, distribution and reproduction in any medium or format, as long as you give appropriate credit to the original author(s) and the source, provide a link to the Creative Commons licence, and indicate if changes were made. The images or other third party material in this article are included in the article's Creative Commons licence, unless indicated otherwise in a credit line to the material. If material is not included in the article's Creative Commons licence and your intended use is not permitted by statutory regulation or exceeds the permitted use, you will need to obtain permission directly from the copyright holder.

To view a copy of this licence, visit http://creativeco mmons.org/licenses/by/4.0/. Open access funding enabled and organized by Projekt DEAL.

The original article has been corrected.

Open Access This article is licensed under a Creative Commons Attribution 4.0 International License, which permits use, sharing, adaptation, distribution and reproduction in any medium or format, as long as you give appropriate credit to the original author(s) and the source, provide a link to the Creative Commons licence, and indicate if changes were made. The images or other third party material in this article are included in the article's Creative Commons licence, unless indicated otherwise in a credit line to the material. If material is not included in the article's Creative Commons licence and your intended use is not permitted by statutory regulation or exceeds the permitted use, you will need to obtain permission directly from the copyright holder. To view a copy of this licence, visit http://creativecommons.org/licenses/by/4.0/.

Publisher's Note Springer Nature remains neutral with regard to jurisdictional claims in published maps and institutional affiliations.

The original article can be found online at https://doi.org/10.1007/ s10772-020-09675-1.

Emilia Parada-Cabaleiro

emipc86@gmail.com

1 Chair of Embedded Intelligence for Health Care and Wellbeing, University of Augsburg, Eichleitnerstr. 30, F2, 86159 Augsburg, Germany

2 GLAM - Group on Language, Audio \& Music, Imperial College London, London, UK 